\title{
Impact of Flexibility of Manufacturing System Components on Competitiveness of SMEs in Northern India
}

\author{
Shakun Preet Kaur ${ }^{1}$, Jatinder Kumar ${ }^{2}$, and Rakesh Kumar ${ }^{3}$ \\ ${ }^{1} \mathrm{PhD}$ student, Department of Mechanical Engineering, NIT, Kurukshetra, India. E-mail: shakunpreet@gmail.com \\ (corresponding author). \\ ${ }^{2}$ Assistant Professor, Department of Mechanical Engineering, NIT, Kurukshetra, India. E-mail: jatin.tiet@gmail.com \\ ${ }^{3}$ Associate Professor, Department of Mechanical Engineering, SBSSTC, Ferozepur, Punjab, India. E-mail: \\ rakesh1607@gmail.com
}

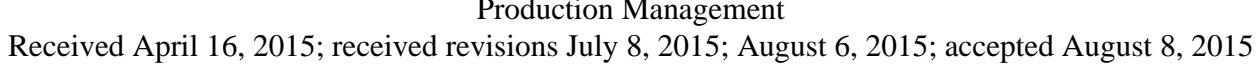

Available online September 16, 2015

\begin{abstract}
The present manufacturing environment is characterized by a number of changes which poses challenges to a typical manufacturing unit. Time demands a shift from the traditional manufacturing strategies as they do not fit to present market competition. A flexible systems strategy has to be designed for remaining competitive in the market and perform well. For designing strategies and policies it is important to know the factors that influence performance of the system. The aim of this paper is to assess the impact of the flexibility of manufacturing system components on competitiveness of SMEs in northern India. A questionnaire based survey was conducted in the SMEs across northern India analysing three sectors namely automotive, machine tool and light engineering (mechanical components and equipment). The study contributes to the existing literature by empirically investigating the impact of machine, material handling and worker flexibility on competitiveness of manufacturing firms. This paper presents a Structural Equation Model displaying the impact of flexibility of manufacturing system components on competitiveness of SMEs.
\end{abstract}

Keywords: Manufacturing system, machine flexibility, material handling flexibility, worker flexibility, competitiveness, SMES, structural equation modelling.

\section{Introduction}

Year after year major changes have been observed in global and national economics and in other relevant areas which directly and/or indirectly influence the manufacturing sector such as availability of resources, skilled workforce; ever demanding customers, changing customer attitudes; environmental issues; collaborations with foreign countries; technical education etc. Manufacturers are finding themselves stuck in 'betterfaster-cheaper' triangle with ever growing prevalence of 'we can have it all' mind-set of customers. Now manufacturers need to meticulously and quickly respond to such environment by suitably adopting and/or adapting various components of the production system (Kumar et al., 2008). In order to sustain in dynamic markets and remain competitive, manufacturing organizations should provide sufficient flexibility in the manufacturing systems. Hence, it becomes essential to study the flexibility of components of the manufacturing systems and their impact on competitiveness.

The paper is divided into five sections. It starts with the introduction to the flexibility of the manufacturing system components and the factors of competitiveness of a firm. Section two gives the details of the research methodology used while section three presents the data analysis and results of various tests. It includes reliability and validity tests, Confirmatory Factor Analysis (CFA) and Structural Equation Modeling (SEM) depicting the impact of manufacturing system components on competitiveness. The forth section is on Discussion and Conclusions, finally the paper ends with the section on Limitations and Future Scope.

\subsection{Flexibility of Manufacturing System Components}

Flexibility is a wide concept used in various disciplines with different contexts. 'The ability to change or react with little penalty in time, effort, cost or performance' (Upton, 1994) can be considered as a comprehensive definition of flexibility. Many authors have given various dimensions related to manufacturing flexibility, but most of them have considered the higher level flexibilities and linked it with strategy and competitiveness. Koste and Malhotra (1999) suggests that three basic flexibility dimensions-machine, labour and material handling appear not to rely on any other flexibility dimensions. These are the lowest level flexibility dimensions which mostly serve as the foundation or building block for higher level dimensions. Hierarchical relationships between these flexibilities do not exist and they are considered to be on the same level independent of each other. Koste and Malhotra (1999) emphasised on range number and heterogeneity of the flexibility dimensions whereas Zhang et al. (2003) added uniformity also to their study of 
analysing and defining relationship among manufacturing competence, capability and customer satisfaction.

Groover (2005) describes that a manufacturing system is a collection of integrated equipment (the integrated equipment includes production machines and tools, material handling and work positioning devices, computer systems etc.) and human resources, whose function is to perform one or more processing/assembling operations on a raw material, part or set of parts. The manufacturing system is considered as the essential component of the production system as it is the place where the value added work is accomplished on the part or the product at ground level to bring it to a desired form. The present study considers the three lower level flexibilities (machine, material handling and worker) which are independent of each other and are considered as building blocks for other flexibilities. The study of flexibility of the components of manufacturing systems ultimately helps in understanding the overall flexibility of the manufacturing system. This study is an attempt to test the impact of flexibility of the components of the manufacturing system on competitiveness of the firm.

\subsubsection{Material handling flexibility}

Material handling comprises of all the sub-systems installed to facilitate the movement of work through the manufacturing system. It includes the pallets to stalk the raw, intermediate or finished products. It also includes the installation of conveyer belts, trolleys, use of robots, AVGs for movement of work. The system can vary from plant to plant depending upon the number of products manufactured, the size and shape of products, the level of automation of the system. Material handling flexibility can be defined as the ability to move the work pieces between different processing centres covering multiple paths economically and effectively (Hutchinson, 1991; Sethi and Sethi, 1990; Coyle et al., 1992; Zhang et al., 2003).

The range and heterogeneity of the material handling system can be considered by looking for the number of paths the system can take in interconnecting to the other machines and the number of different shapes and sizes of materials that can be transported within the system. The factors considered in this study on which flexibility of material handling systems is measured are the capability to support quick changeovers, flexibility of having alternative paths, handle different shapes/sizes of work and level of automation.

\subsubsection{Machine flexibility}

In the present study term machine is used for all the machinery, fixtures and tools related to manufacture product installed in a manufacturing system. The machinery used for manufacturing also varies from plant to plant depending upon the type of products manufactured, the size and shape of products, the level of automation of the system.

Machine flexibility is any equipment's ability to perform different operations/tasks economically and effectively (Gupta, 1993; Hyun and Ahn, 1992; Chen et al., 1992; Sethi and Sethi, 1990; Zhang et al., 2003). Browne (1984) defined it as the ease of making the changes required to produce a given set of part types. Koste and Malhotra (1999) differentiated this flexibility as the range and heterogeneity in operations. The concept there after has been picked up by authors for designing instruments for checking machine flexibility. The variables of machine flexibility taken up in this study is level of automation; time required for changeovers and producing new products; machine capacity and availability; capability of accommodating new fixtures.

\subsubsection{Worker flexibility}

Worker/Labour in a manufacturing system comprises of all work force on the shop floor to facilitate the manufacturing. The capability required from workers varies from plant to plant and department to department depending upon the level and type of skill required for manufacturing. Worker/Labour flexibility is the ability of the worker to perform a wide range of manufacturing related tasks economically and effectively (Upton, 1994; Hyun and Ahn, 1992; Ramasesh and Jayakumar, 1991; Zhang et al., 2003). The worker/labour flexibility plays a vital role in enhancing the performance of a firm (Koste and Malhotra, 1999). They support the thought that if a worker is cross trained within or across other departments, the level of heterogeneity of work handled by labour/worker is increased which enhances worker/labour flexibility. Flexible workers are apt to handle internal/external uncertainty in the production process such as absenteeism (Zhang et al., 2003), change in volume of demand and design as per the requirement of customer. It is also supported by Francas et al. (2011) that the ease of transfer of labour between the departments leads to the labour flexibility. In the present study this flexibility is measured by the workers' capability to work on more than one machine at a time, on machine with multiple operations, the ability to operate various machines, altering of working methods, availability of workers when there is change in demand and product design variations, ease to transfer between organizational units and departments.

\subsection{Competitiveness}

Competitiveness is based on how good is the performance of the organization. Various authors gave certain measures of performance which in general includes productivity, flexibility, quality, cost and time. As described by Kapoor in 2011, competitiveness is the productivity with which the nation utilizes its various recourses. It is not what industries, a nation competes in that matter for prosperity, but how firms compete in those industries. Taking this idea further this paper describes how the firms compete in the Indian manufacturing industries, their level of competitiveness and the relationship between the components of manufacturing flexibility and competitiveness.

Competitiveness is a very controversial topic which involves multidimensional concepts and disciplines (Tomas, 2011). Li et al. (2009) quoted that study of competitiveness helps to form a sound basis for business strategy development and hence has become extremely popular with management theorists and practitioners. To provide customers a higher value for money and satisfaction with respect to the competitors, firms should be operating efficiently, cost effectively and be quality conscious (Ambastha and Momaya, 2005). Competitiveness according to customers (Li et al., 2009) involves a combination of assets (created or inherited) and processes which changes the assets into economic gains. Mehmet et al. (2013) quoted that firms competing on an open market are under high pressure of adjusting price of 
their products to meet the needs and expectations of customers. A firm has competitive advantages if it can produce and sell products at lower price than its competitors without subsidies or if develops unique features and innovative products (Rojaka, 2009). To sustain in this race, the firms has to function efficiently. Failing to do so, the firms will have to exit the market (Schuller and Lidbom, 2009).

ElMaraghy (2006) states that people play an important role in the operation and success of manufacturing systems and hence the competitiveness of the industrial enterprise. Manufacturers, in their pursuit of productivity and profitability, have now realized that ensuring people involvement in decision making and operation of manufacturing systems is critical to their success and competitiveness. He has also quoted that the main challenges include the design of machines, systems and controls for flexibility; changeability and reconfiguration and integration with current systems and software and defining a total productivity measure which considers all elements and trade-offs.

Firms competitiveness studied in literature can be divided in some schools of thought like competitive advantage and competitive strategy models (Porter, 1990); Resource-Based View (RBV) and core competence approach (Wernerfelt, 1984; Prahalad and Hamel, 1990; Barney, 1991); and the strategic characterized approach by an industrial organization view (Li et al., 2009; Mehmet et al., 2013). Porter's framework proposes that firms that pursue any of the cost or differentiation competitive strategies would develop a competitive advantage that would enable them to outperform competitors in their industry. However, for a firm to earn superior profits and outperform its competitors, it must make a clear choice between a cost leadership and differentiation strategy in order to avoid 'the inherent contradictions of different strategies' (Porter, 1996). Kawsi and Moses (2007) suggest a model that firm performance is directly affected by competitive strategy (cost leadership and differentiation) and manufacturing strategy (cost, delivery, flexibility, and quality). Firm performance is also affected indirectly by competitive strategy through manufacturing strategy. Thus manufacturing strategy may mediate the relationship between competitive strategy and firm performance. Their results indicated that out of the four (cost, delivery, flexibility and quality) the quality influenced the performance; the competitive strategy did not have any direct relationship with firm performance though it was indirectly related through quality.

Long-term competitiveness is dependent on the company's take on continuous improvement in quality and reliability of the product by fostering strategies and proper knowledge sharing (Karim et al., 2008). Avella et al. (2001) studied in their research work that whether the manufacturing strategy content is an explanatory factor of firms' competitiveness or the firms' manufacturing strategy effects the business performance. In their study they considered cost, quality, flexibility and delivery as the manufacturing competitive capabilities. Their results indicated firms do not have clearly specified manufacturing competitive priorities and practices which enables the firm to achieve such competitive priorities and hence business performance and they are still at 'externally neutral stage' as described by Hayes and Wheelwright (1984) and Hayes et al. (1988).
Long term planning for competitiveness leads to being in business for a longer time. Salloum (2013) studied about the performance measures with a dual case study approach. Here he came out with five perspectives of performance measurements for the first company namely, safety, quality, delivery, cost and human resource. The perspectives identified for second company were safety, environment, quality, delivery, cost and human resource. Further he measured the variation in performance measurement under these variables. He concluded that the reason for change in performance measurement is changing environment. Karim et al. (2008) in his study quotes the comparison of competitive priorities in order of their degree of importance in various countries which is as follows, US: conformance quality, product reliability, ontime delivery, low price, fast delivery; Europe: conformance quality, product reliability, on-time delivery, low price, fast delivery; Japan: low price, product reliability, on-time delivery, fast delivery, new products speed; Australia: company reputation, product quality \& reliability, design and manufacturing capability, on-time delivery, price; Malaysia: product quality \& reliability, company reputation, marketing, price, design and manufacturing capability. Joshi et al. (2013) studied about Supply chain competitiveness in an automotive component manufacturing industry. The competitive priority variables in the study included quality, cost, flexibility, delivery, buyer supplier relationship, technology, environmental factors and customer satisfaction. The evaluation of level of competitiveness of any industry can be judged on how well the industry is doing on the price offered, responding to changes (Slack, 1988), quality issues, product variants, delivery issues etc. (Tracy et al., 1999). In light of the above discussion and the practical constrains of considering only the SMEs four priorities of competitiveness are taken up in this study which are: price offered, quality, delivery and product line breadth.

\subsubsection{Price offered}

The price offered on products since olden times are the set priority of competitiveness of any firm. The price offered should be such that all the costs incurred while manufacturing the product to reach the customer and the profits earned by the firm should be included in it. The challenge lies where the firms have to offer prices in comparison with the competitors to remain in the business. The present study offers to examine price as a competitive priority by evaluating that whether the organizations offer competitive prices; are they able to compete based on prices and are they able to profitably offer as low as their competitor.

\subsubsection{Quality}

The quality of a product is undoubtedly regarded as a competitive priority globally. Quality is defined as the fitness to use, which includes aspects like product performance, durability and reliability. This competitive priority greatly depends on the design specifications and the manufacturing capabilities and capacity. The variables of quality taken up in this study is to check that are organizations manufacturing products that conform to specifications; warranty or guarantee claimed; their ability to compete based on quality and offering reliable and durable products. 


\subsubsection{Delivery}

The delivery of a product has been taken up as a competitive priority globally after the supply chain has become a key parameter in operations. The delivery performance depends on the two aspects majorly i.e. time and the volume to be delivered. The concepts of lean manufacturing and zero inventory adopted by companies have made the delivery as an important competitive priority. The delivery of a firm is examined on its capability of providing on-time delivery of orders; accommodation of variation in order sizes without affecting delivery performance; altering delivery schedule as per each customer's requirement and frequency of customer back orders.

\subsubsection{Product line breadth}

The customer requirements change on a very high rate. They expect the availability of products that suit to their changing requirements. The ability of providing larger variety of products, the variety of new products and the capability of change in design of existing products makes product line breadth an important competitive priority. The sales performance and the market share depend on the capability of providing a broader product line. The variables considered for product line breadth are that the organizations providing a large range of products; change in design at low cost; economically produce new products and launch products with latest technology and design as compared to their competitors.

\subsection{The Hypothesis Tested}

The objective of the paper is to study the impact of flexibility of manufacturing system components on competitiveness of the organization. For carrying out this study following hypothesis are formed.

Null Hypothesis: There is no significant impact of manufacturing system components flexibility of SMEs on their level of competitiveness.

Alternate Hypothesis: Manufacturing system components flexibility of SMEs has a significant impact on their level of competitiveness.

\section{Research Methodology}

The primary data in the research study is collected using a self-designed questionnaire via telephonic interview, survey, and email from senior plant managers, operation heads, marketing heads, production managers, senior quality control personals working with SMEs of automotive, light engineering (mechanical component and equipment) and machine tool manufacturing sector in different parts of northern India. The questionnaire is shown in Appendix. Multistage random cluster sampling method is used in this research study for sample selection. Random sampling was done from the clusters of automotive, light engineering (mechanical component and equipment) and machine tool manufacturing firms (SMEs). A total of 330 questionnaires were filled out of which 28 were found to be incomplete so they were rejected and the remaining 302 were finally selected for the study. The distribution of the sample is as shown in Table 1 and Fig. 1. The internal consistent reliability of the different constructs used in the questionnaire is measured by Cronbach Alpha and construct validity (convergent as well as discriminant validity) is analysed by Confirmatory Factor Analysis. Finally through Structural Equation Modelling (SEM) a model is suggested representing the impact of flexibility of manufacturing system components on competitiveness of the organization. SEM is a statistical technique for constructing and testing statistical models, which are often underlying models. It is a technique that incorporates aspects of Confirmatory Factor Analysis, path analysis and regression, which can be seen as special cases of SEM. SEM is an extension of the general linear model that simultaneously estimates relationships between multiple independent, dependent and latent variables. In the study we use Confirmatory Factor Analysis followed by Structural Equation Modelling and estimating relationships between multiple independent, dependent and latent variables, where the components of the flexibility of the manufacturing system is considered to be the independent latent variables and competitiveness a dependent latent variable.

Table 1. The frequency distribution of the sample (based on sector)

\begin{tabular}{ccccr}
\hline Sector & Frequency & Percent & Valid Percent & Cumulative Percent \\
\hline Machine tools & 100 & 33.1 & 33.1 & 33.1 \\
Automotive & 104 & 34.4 & 34.4 & 67.5 \\
Light engineering (Mechanical equipment & 98 & 32.5 & 32.5 & 100.0 \\
\& components) & & 100.0 & 100.0 \\
$\quad$ Total & 302 & 100.0 & \\
\hline
\end{tabular}




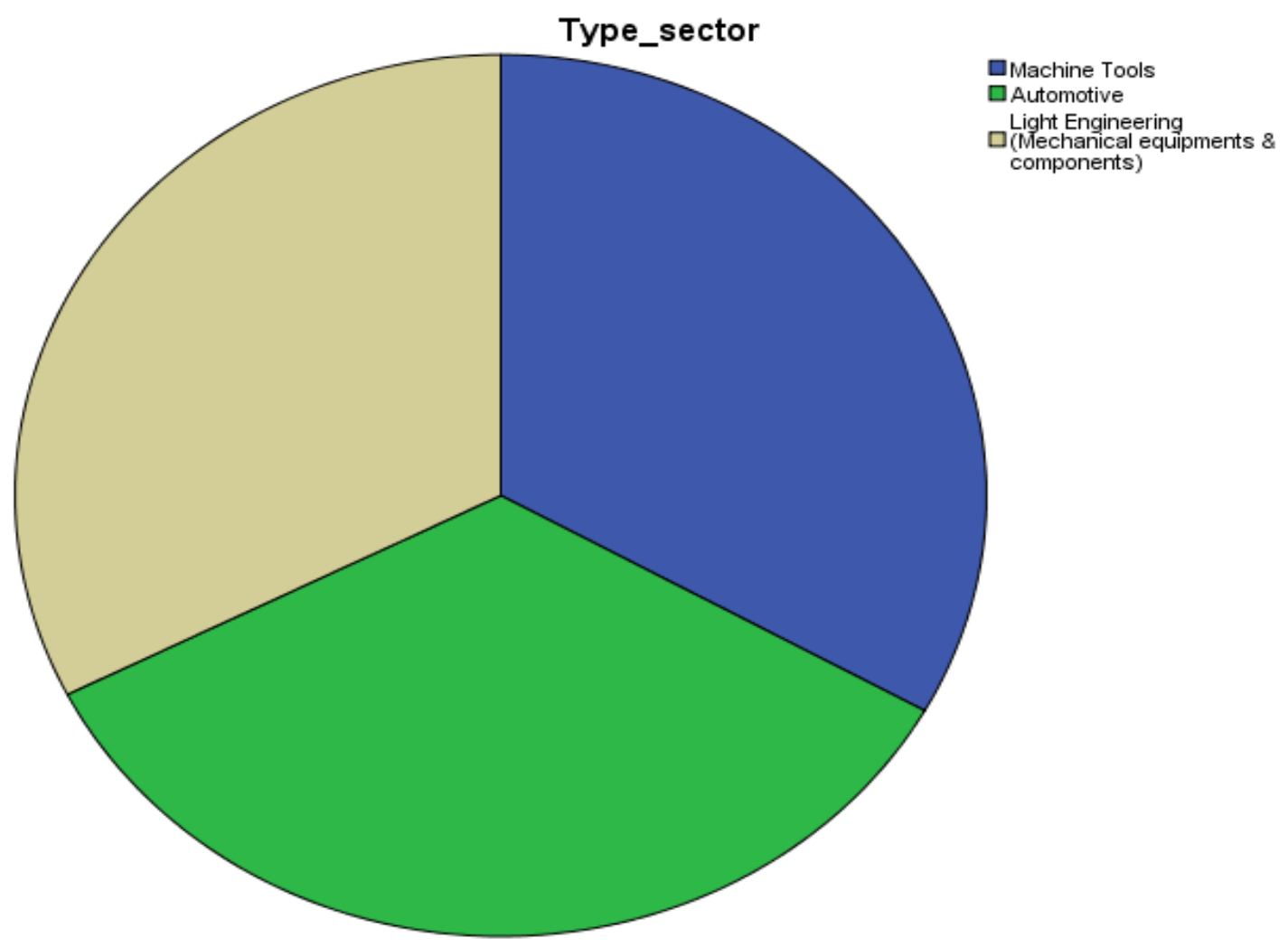

Fig. 1. The frequency distribution of the sample (based on sector)

\section{Data Analysis and Results}

In the present study, MS Excel, AMOS 21 and SPSS 21 software are used for the statistical analysis of the data.

\subsection{Reliability and Validity Analysis}

The flexibility of components of a manufacturing system and competitiveness of firms are measured with the help of a questionnaire. Analysis of the data generated from the designed questionnaire is done to confirm the reliability and validity. The Cronbach Alpha value indicates the internal consistent reliability of the construct. The Cronbach reliability check analysis of the questionnaire used in the literature is as described: its value lies between 0 and 1 and a value of 0.6 or less generally indicates unsatisfactory internal consistency.

The validity of a scale may be defined as the extent to which differences in observed scale scores reflect true differences among objects on the characteristic being measured, rather than systematic or random error. The construct validity is the type of validity that addresses the question of what constructs the scale is measuring. The convergent and divergent validity tests are conducted for the present study. Convergent validity is the measure of construct validity that measures the extent to which the scale relates positively with other measures of the same construct whereas the discriminant validity is the type of construct validity that assesses the extent to which a measure doesn't correlate with other constructs from which it's supposed to differ (Malhotra and Dash, 2011) .The Composite Reliability (CR) statistic if found to be higher than among the extracted statistics, the convergent validity of the construct is ensured. In addition to this if the Average Variance Extracted (AVE) is also found to be higher than Maximum Shared Variance (MSV) as well as Average Shared Variance (ASV) it indicates that the construct is valid with respect to discriminant validity which further indicates that the construct measured by the given variables is a reliable and valid construct.

The analysis of the same is shown in Table 2 and Table 3 indicating that the material handling flexibility, machine flexibility and the worker flexibility measured by four, eight and seven variables respectively are a reliable and valid construct. Also the competitive priorities i.e. the price offered (three variables), quality (four variables), delivery (four variables) and product line breadth (four variables) are reliable and valid construct. The results of Cronbach Alpha as shown in Table 2 and Table 3 prove that the questionnaire is credible. The details of the variables are shown in the appendix attached.

\subsection{Confirmatory Factor Analysis (CFA)}

Confirmatory Factor Analysis (CFA) is a modified form of factor analysis. In CFA all constructs are analysed together along with their measured variables. The correlation between different pairs of constructs is analysed in order to check the discriminant validity of the constructs. In addition to discriminant validity, the convergent validity of the constructs is also tested with CFA. In the present research study it is assumed that the three considered components of the manufacturing systems are independent components. Also, the four priorities of competitiveness are independent components. In order to check the convergent as well as the discriminant validity of these three components of manufacturing system Confirmatory Factor Analysis (CFA) is done (Fig. 2). 
Table 2. Reliability and validity analysis (manufacturing system components)

\begin{tabular}{ccccccc}
\hline Construct & $\begin{array}{c}\text { No of } \\
\text { Variables }\end{array}$ & $\begin{array}{c}\text { Cronbach } \\
\text { Alpha }\end{array}$ & $\begin{array}{c}\text { Composite } \\
\text { Reliability } \\
\text { (CR) }\end{array}$ & $\begin{array}{c}\text { Average } \\
\text { Variance } \\
\text { Extracted } \\
\text { (AVE) }\end{array}$ & $\begin{array}{c}\text { Maximum } \\
\text { Shared } \\
\text { Variance } \\
\text { (MSV) }\end{array}$ & $\begin{array}{c}\text { Average } \\
\text { Shared } \\
\text { Variance } \\
\text { (ASV) }\end{array}$ \\
\hline Material Handling & 4 & 0.904 & 0.905 & 0.708 & 0.362 & 0.334 \\
Machine & 8 & 0.947 & 0.948 & 0.693 & 0.387 & 0.286 \\
Worker & 7 & 0.934 & 0.935 & 0.675 & 0.306 & 0.266 \\
\hline
\end{tabular}

Table 3. Reliability and validity analysis (competitive priorities)

\begin{tabular}{ccccccc}
\hline Construct & $\begin{array}{c}\text { No of } \\
\text { Variables }\end{array}$ & $\begin{array}{c}\text { Cronbach } \\
\text { Alpha }\end{array}$ & $\begin{array}{c}\text { Composite } \\
\text { Reliability } \\
\text { (CR) }\end{array}$ & $\begin{array}{c}\text { Average } \\
\text { Variance } \\
\text { Extracted } \\
\text { (AVE) }\end{array}$ & $\begin{array}{c}\text { Maximum } \\
\text { Shared } \\
\text { Variance } \\
\text { (MSV) }\end{array}$ & $\begin{array}{c}\text { Average } \\
\text { Shared } \\
\text { Variance } \\
(\text { ASV) }\end{array}$ \\
\hline Price offered & 3 & 0.896 & 0.9 & 0.751 & 0.197 & 0.14 \\
Quality & 4 & 0.857 & 0.862 & 0.618 & 0.197 & 0.132 \\
Product Line Breadth & 4 & 0.869 & 0.872 & 0.633 & 0.181 & 0.149 \\
Delivery & 4 & 0.9 & 0.902 & 0.698 & 0.181 & 0.112 \\
\hline
\end{tabular}

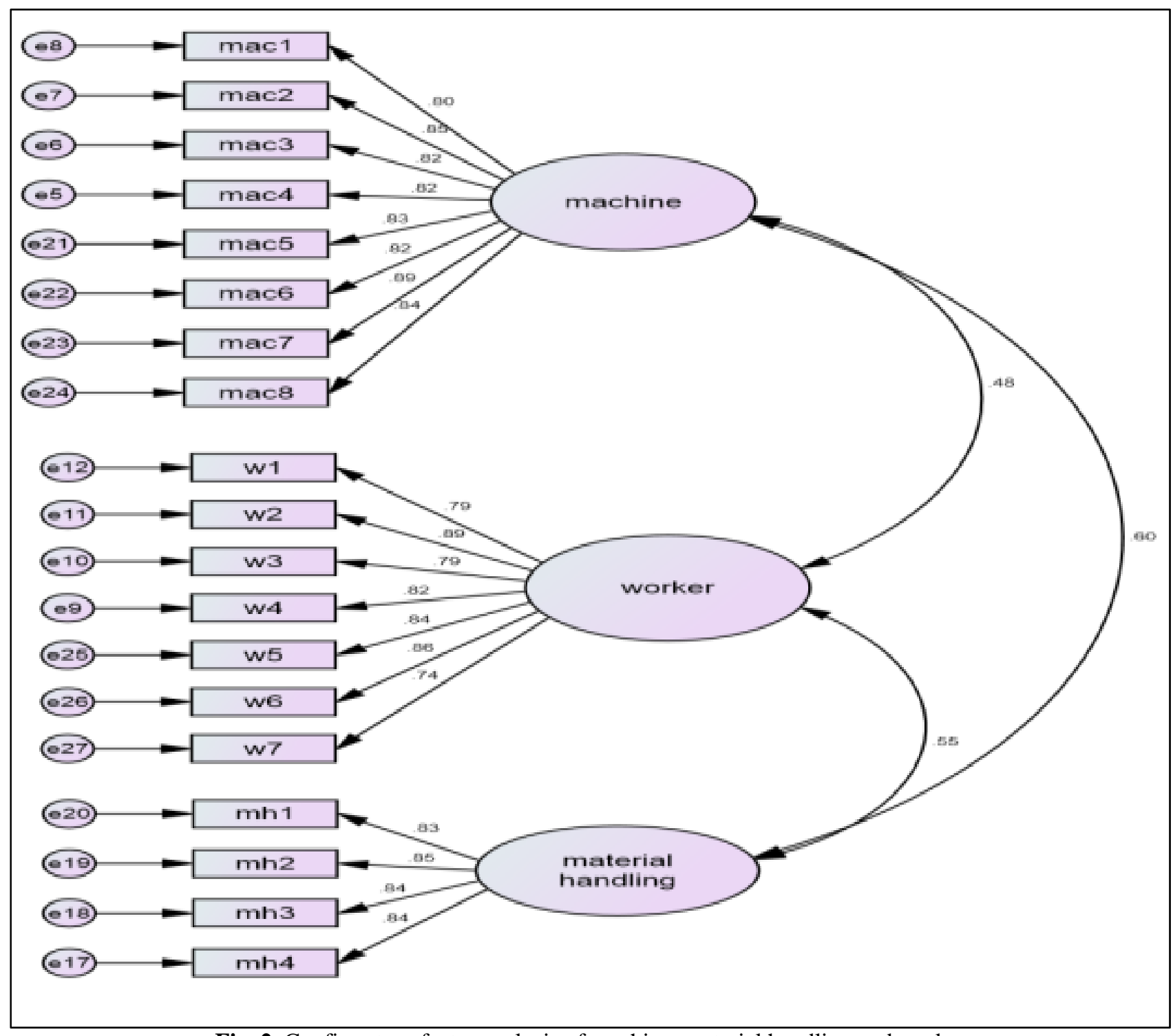

Fig. 2. Confirmatory factor analysis of machine, material handling and worker 
In order to achieve convergent validity the Composite Reliability (CR) should be more than 0.7, Average Variance Extracted (AVE) should be more than 0.5 and value of Composite Reliability (CR) should be more than Average Variance Extracted (AVE). For discriminant validity the Average Variance Extracted (AVE) should be greater than Average Shared Variance (ASV) and Maximum Shared Variance (MSV) (Malhotra and Dash, 2011).

Results of the Confirmatory Factor Analysis (CFA) are shown in the Table 4. The results indicate that all the above mentioned conditions for convergent as well as discriminant validity is fulfilled. Hence it can be concluded that all the three components of manufacturing system are independent to each other and can be measured by the variables considered in the research study.

In the research study it is assumed that the four priorities of competitiveness i.e. price offered, quality, delivery and the product line breadth are independent components. In order to check the convergent as well as the discriminant validity of these four priorities of Competitiveness Confirmatory Factor Analysis (CFA) is done (Fig. 3).

Results of the CFA are shown in Table 5. The results indicate all the above mentioned conditions for convergent as well as discriminant validity is fulfilled. Hence, it can be concluded that all the four priorities of competitiveness i.e. price offered, quality, delivery and the product line breadth are independent to each other and can be measured by the variables considered in the research study.

\subsection{Impact of Flexibility}

The objective of the paper is to study the impact of flexibility of manufacturing system components on competitiveness of the organization. There is no empirical evidence linking the competitive priorities and specific measures of machine and material handling flexibility. However, Karuppan, and Ganster (2004) quoted that flexible machines are used to support multiple priorities unless there is emphasis on cost. The machine flexibility supports in a reduction in setup costs, increased variety and small volume production. The research in the past indicates that labour flexibility fits a strategic emphasis on quality (Malhotra and Ritzman, 1990; Polakoff, 1991; Jayaram et al., 1999; Karuppan, and Ganster, 2004) which is a very important competitive priority. Karuppan, and Ganster in 2004 quoted that labour flexibility (range number) is having in depth skills in one area (high quality and thus lower failure costs). Labour flexibility (range heterogeneity) involves broader skills but is more expensive.
After discussing the individual constructs in the previous sections this section tests the hypothesis stated in section 1.3. The Structural Equation Model (SEM) approach is applied to study the cause and effect relation between flexibility of manufacturing system components and competitiveness. The proposed model is shown in Fig. 4.

The flexibility of manufacturing system is explained by the flexibility of its components i.e. machine, worker and material handling system. The SEM diagram (as shown in Fig. 4) indicates cause and effect relationships among the endogenous and exogenous constructs. An exogenous construct is the latent, multi-item equivalent of an independent variable in the traditional multivariate analysis whereas endogenous construct is the latent, multiitem equivalent of an dependent variable in the traditional multivariate analysis (Malhotra and Dash, 2011) .The results of SEM is shown in the Table 6.

The results indicate that the probability value of critical ratios of the entire exogenous construct is less than 5 percent level of significance. Hence, with 95 percent level of confidence, it can be concluded that all the components representing flexibility of manufacturing system is having the significant impact on competitiveness. Hence, the alternate hypothesis is accepted.

The results also indicate that among the three different components of flexibility of manufacturing system the flexibility of the worker is found to be having the highest impact on competitiveness followed by the flexibility of machine and material handling systems. This indicates that the workers availability and capability are the most important factors which impact the competitiveness. The workers play a major role in operating machines. The work handling systems in Indian SMEs are found to be lying in the manual to semiautomatic range which indicates workers' high involvement. Next to worker the flexibility of machine i.e. ease with which the machine can perform more operations is found to be impacting competitiveness. Hence good machinery and workforce is required for achieving the competitive advantage. The squared multiple correlation of 0.406 indicates that 40.6 percent of the variations in competitiveness can be explained by this structural model. In other words the flexibility of different components of manufacturing system accounts for 40.6 percent of the variations in competitiveness.

Table 7 indicates the statistical fitness of the measurement model. The result indicates that the goodness of fit indices is found to be close to one as well as the badness of fit indices is significantly low. Hence it may be concluded that the model is statistically fit. 
Table 4. Results of confirmatory factor analysis

\begin{tabular}{|c|c|c|c|c|c|c|c|}
\hline Construct & $\begin{array}{c}\text { Composite } \\
\text { Reliability } \\
\text { (CR) }\end{array}$ & $\begin{array}{c}\text { Average } \\
\text { Variance } \\
\text { Extracted } \\
\text { (AVE) }\end{array}$ & $\begin{array}{c}\text { Maximum } \\
\text { Shared } \\
\text { Variance } \\
\text { (MSV) }\end{array}$ & $\begin{array}{c}\text { Average } \\
\text { Shared } \\
\text { Variance } \\
\text { (ASV) }\end{array}$ & Worker & Machine & $\begin{array}{l}\text { Material } \\
\text { Handling }\end{array}$ \\
\hline Worker & 0.935 & 0.675 & 0.306 & 0.266 & 0.822 & & \\
\hline Machine & 0.948 & 0.694 & 0.362 & 0.294 & 0.476 & 0.833 & \\
\hline $\begin{array}{l}\text { Material } \\
\text { Handling }\end{array}$ & 0.906 & 0.706 & 0.362 & 0.334 & 0.553 & 0.602 & 0.840 \\
\hline
\end{tabular}

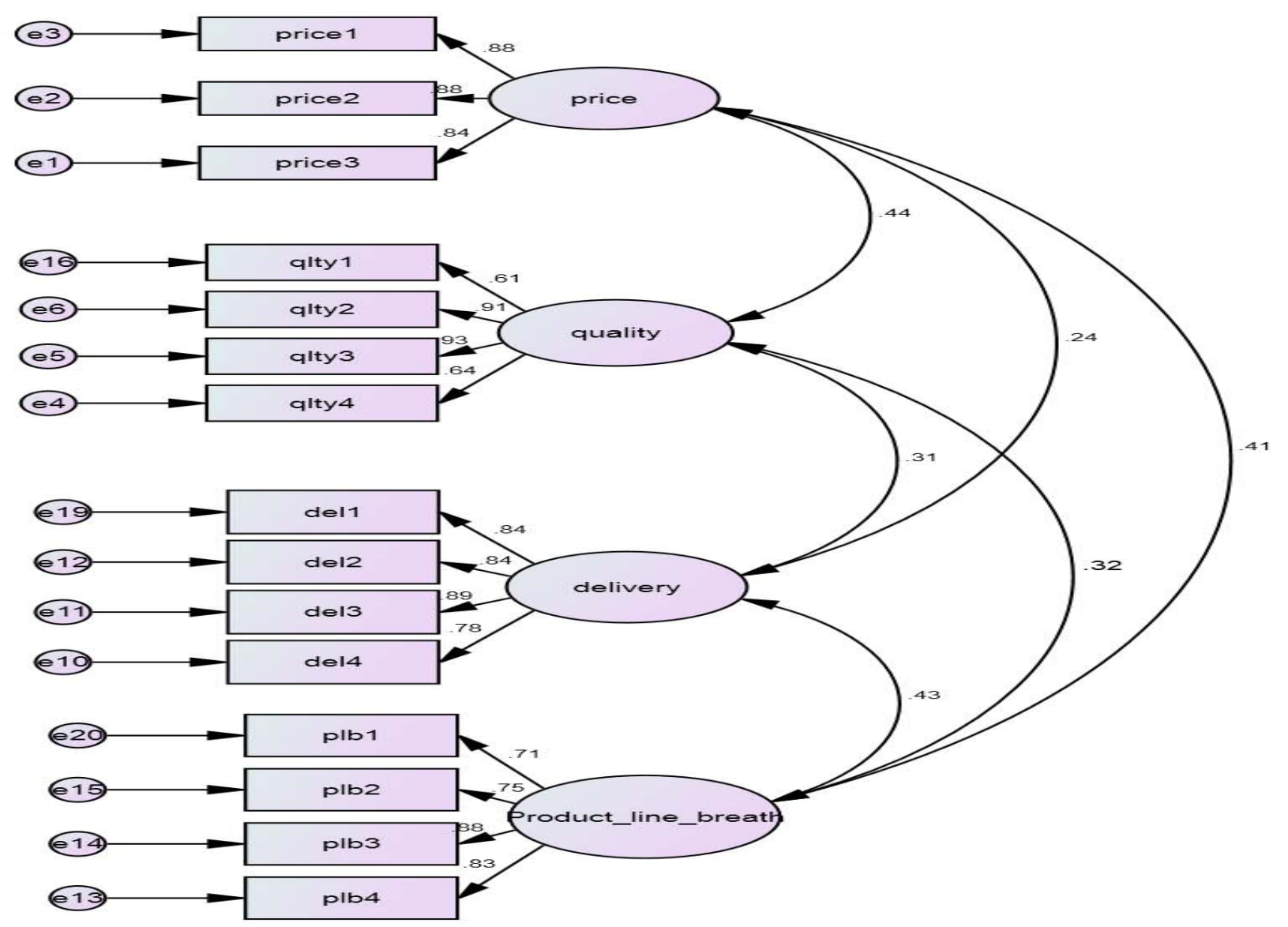

Fig. 3. Confirmatory factor analysis of price offered, quality, delivery and the product line breadth

Table 5. Results of confirmatory factor analysis

\begin{tabular}{|c|c|c|c|c|c|c|c|c|}
\hline Construct & $\begin{array}{c}\text { Composite } \\
\text { Reliability } \\
\text { (CR) }\end{array}$ & $\begin{array}{c}\text { Average } \\
\text { Variance } \\
\text { Extracted } \\
\text { (AVE) }\end{array}$ & $\begin{array}{l}\text { Maximum } \\
\text { Shared } \\
\text { Variance } \\
\text { (MSV) }\end{array}$ & $\begin{array}{c}\text { Average } \\
\text { Shared } \\
\text { Variance } \\
\text { (ASV) }\end{array}$ & Delivery & $\begin{array}{c}\text { Price } \\
\text { Offered }\end{array}$ & Quality & $\begin{array}{l}\text { Product } \\
\text { Line } \\
\text { Breadth }\end{array}$ \\
\hline Delivery & 0.902 & 0.698 & 0.181 & 0.112 & 0.836 & & & \\
\hline $\begin{array}{c}\text { Price } \\
\text { Offered }\end{array}$ & 0.900 & 0.751 & 0.197 & 0.140 & 0.238 & 0.866 & & \\
\hline Quality & 0.862 & 0.618 & 0.197 & 0.132 & 0.311 & 0.444 & 0.786 & \\
\hline $\begin{array}{l}\text { Product Line } \\
\text { Breadth }\end{array}$ & 0.872 & 0.633 & 0.181 & 0.149 & 0.426 & 0.406 & 0.318 & 0.795 \\
\hline
\end{tabular}




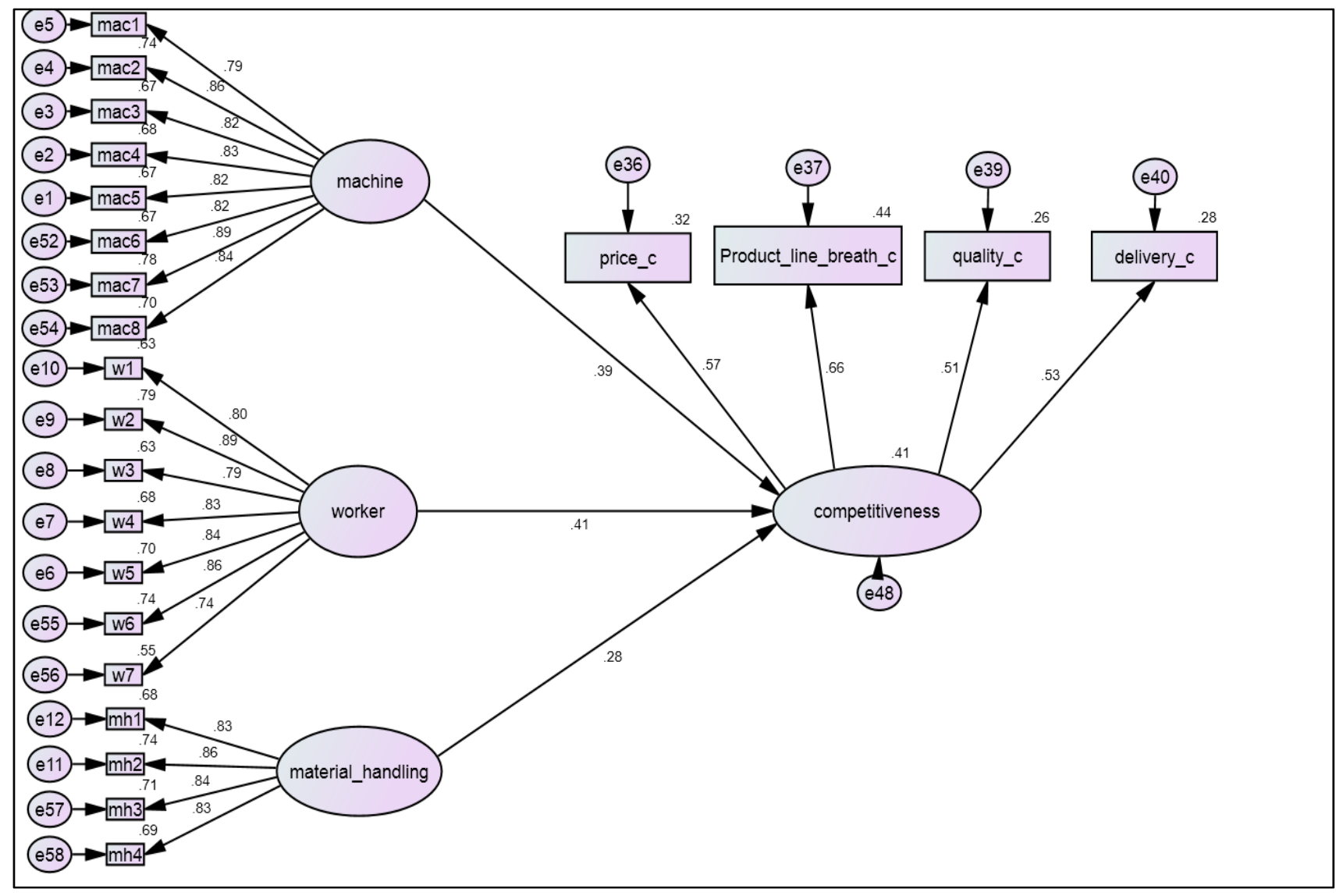

Fig. 4. Proposed SEM model representing: Impact of flexibility of manufacturing system components on competitiveness

Table 6. Results of SEM: Impact of flexibility of manufacturing system components on competitiveness

\begin{tabular}{ccccccc}
\hline \multirow{2}{*}{$\begin{array}{c}\text { Endogenous } \\
\text { Constructs }\end{array}$} & $\begin{array}{c}\text { Exogenous } \\
\text { Constructs }\end{array}$ & $\begin{array}{c}\text { Standardised } \\
\text { Regression } \\
\text { Coefficient }\end{array}$ & $\begin{array}{c}\text { Unstandardized } \\
\text { Regression } \\
\text { Coefficient }\end{array}$ & CR & P Value & R Square \\
\cline { 2 - 6 } Competitiveness & $\begin{array}{c}\text { Machine } \\
\text { Handling }\end{array}$ & 0.394 & 0.200 & 5.305 & 0.000 & $40.6 \%$ \\
\cline { 2 - 6 } & Worker & 0.412 & 0.134 & 4.059 & 0.000 & 0.000 \\
\hline
\end{tabular}

Table 7. Model fit indices SEM

\begin{tabular}{ccccccccc}
\hline \multirow{2}{*}{ Model Fit } & \multicolumn{3}{c}{ Goodness of Fit Indices } & \multicolumn{3}{c}{ Badness of Fit Indices } \\
\cline { 2 - 26 } & CFI & GFI & AGFI & NFI & RMSEA & LO90 & H90 \\
\hline Value & 0.827 & 0.763 & 0.711 & 0.796 & 0.120 & 0.113 & 0.126 \\
\hline
\end{tabular}

\section{Discussion and Conclusions}

Flexibility has long been recognized as a manufacturing capability that has the potential to impact the competitive position and the business performance of an organization. Boyer and Leong (1996) considered manufacturing flexibility as an important element of firm's manufacturing strategy which provides the capability to respond to market uncertainty. Flexibility as a broader aspect is the key factor in determining the competitive position and formulating the manufacturing strategy of a firm (Buffa, 1984; Fine and Hax, 1985; Hayes and Wheelwright, 1984; Leong et al., 1990). Manufacturing flexibility is one of the solutions to problem caused by constantly changing and uncertain environment (Swamidass and Newel, 1987).

The present study contributes to the existing literature by empirically investigating the impact of machine, material handling, and worker flexibility on competitiveness of manufacturing firms. It presents a Structural Equation Model displaying the impact of flexibility of manufacturing system components on competitiveness of SMEs.

The results of the status of individual variables of flexibility of components of manufacturing system are 
indicated in the figure of Confirmatory Factor Analysis of the constructs: machine, material handling and worker (Fig. 2).

- The extent to which the material handling system can depart from its normal flow and move materials in alternative paths explains the maximum variance of the material handling construct with standardised regression coefficient of $0.86(\mathrm{MH} 2)$, this is due to the fact that the material handling system in the north Indian SMEs is manual or semiautomatic which can be easily reprogrammed to take different or alternative paths in the system.

- The maximum variance of the machine flexibility is explained by the ability of the machine to have automatic tool change between operations with standardised regression coefficient of 0.89 (MAC 7) (Fig. 2). This is due to the fact that the machine tool change time governs the lead time and this results in timely and frequent delivery. Followed by 'total number of operations that a machine can perform is high' with standardised regression coefficient of 0.86 (MAC 2), which indicates that the setups which use multipurpose machines will be more machine flexible. Using multipurpose machinery is an indicator of being flexible if it is chosen considering cost, extended product range and space constraints.

- Maximum variance of the worker flexibility as obtained from the results of the study is explained by 'the extent to which the workers are comfortable to work on machine with multiple operations'. This is due to the fact that the machines used in these setups are having multiple operations as indicated in the result of machine flexibility and the workers who are comfortable to work on them will have more flexibility. This is explained with the standardised regression coefficient of 0.89 (W 2).

The status of the variables of competitive priorities is depicted by Confirmatory Factor Analysis of the constructs: price offered, quality, delivery and the product line breadth in Fig. 3.

- The firms in Northern India are able to compete based on the prices they offer (Price 2 with 0.884 standardised regression coefficient) which is due to the fact that the prices offered affects the sales volume and market share .

- Quality is undoubtedly a very important aspect of doing business. The results indicate that the ability to compete based on the quality is the variable of greatest importance (QLTY 3 with 0.91 standardised regression coefficient). Giving reliable, durable or products as per specifications is a must and mandatory but having quality as a competitive edge over competitors is of great importance.

- Results for delivery as a competitive priority indicate that the maximum variance of the delivery is explained by the ability of the firm to alter delivery schedules (DEL 3 with 0.89 standardised regression coefficient). This indicates that the customers are happy if any vendor is able to accommodate the changes in delivery schedules, either pre or post which helps the customers to follow JIT or lean practices and vendors gain a competitive edge over it. It also improves on the supply chain activity on the customer end.

- Maximum variance of the product line breadth construct is explained by the ability of the firm to launch new products at low cost (Plb 3 with 0.89 standardised regression coefficient). This indicates that irrespective of innovation or technology change, still the bottom line of manufacturers is to manufacture new products at low cost. This gives them a competitive advantage as increase in profits and the product can be further sold at competitive prices.

Finally the SEM reflects that flexibility of components of manufacturing system impacts the competitiveness of the firm, which was unexplored in the context of North Indian SMEs. Thus, these low level flexibilities (machine, material handling and worker) or the basic flexibilities have impact on the competitiveness. Out of the components of the manufacturing system, worker flexibility has the greatest impact on competitiveness followed by machine flexibility with a marginal difference. This suggests that though the automated machinery plays an important role in describing the flexibility of a manufacturing system but having and retaining a skilled workforce is also important. Worker as compared to any equipment is considered to be a more adjustable resource. The study proves that the worker and machine flexibility have a leading role in building competitive strengths.

\section{Limitations and Future Scope}

The present study has revealed the status of manufacturing system components and competitive priorities of manufacturing SMEs in northern Indian. It also reflects the impact of manufacturing system components on competitiveness. This paper has limitations which are common to all such studies i.e. there is a possibility of some region/country bias because only north Indian firms have been analysed. The results probably may not be generalised as there may be variations in the findings when other sectors are studied. Also, the results may vary when large enterprises or MNC's are considered.

Further scope of study may include other sectors/region for testing the hypothesis. Comparison between the results of the chosen sectors/regions can be done. Competitiveness can also be linked with business performance and the results checked. Other factors for competitiveness i.e. marketing, company reputation etc. can also be included for future study.

\section{References}

Ambastha, A. and Momaya, K., (2005). Competitiveness of Firms: Review of Theory, Frameworks, and Models. Singapore Management Review, 26(1), 45-61. Avella, L., FernaHndez, E., and VaHzquez, J. C., (2001). Analysis of manufacturing strategy as an explanatory factor of competitiveness in the large Spanish industrial firm. Int. J. Production Economics, 72, 139157. 
Barney, B. J., (1991). Firm Resources and Sustained Competitive Advantages. Journal of Management, 17(1), 99-120.

Browne, J., Dubois, D., Rathmill, K., Sethi, S. P., and Stecke, K. E., (1984). Classification of flexible manufacturing systems. The FMS Magazine, 2(2), 114-117.

Boyer, K. K. and Leong, G. K., (1996). Manufacturing Flexibility at the Plant Level. Omega, Int. J. Mgmt Sci., 24(5), 495-51.

Buffa, E. S., (1984). Meeting the Competitive Challenge. Dow Jones-Irvin, Illinois.

Chen, I. J., Calantone, R. J., and Chung, C. H., (1992). The marketing manufacturing interface and manufacturing flexibility. Omega, 20(4), 431-443.

Coyle, J. J., Bardi, E. J., and Novack, R. A., (1992). The Management of Business Logistics, 5th Edition. West Publishing.

ElMaraghy, H. A., (2006). Flexible and Reconfigurable Manufacturing System paradigms. Int. J. of Manf Syst, 17, 261-276.

Fine, C. H. and Hax, A. C., (1985). Manufacturing strategy: a methodology and an illustration. Interfaces, 15, 28-46.

Francas, D., Lohndorf, N., and Minner, S., (2011). Machine and Labour flexibility in manufacturing networks. Int. J. Production Economics, 131, 165-174.

Groover, M. P, (2005). Automation, production systems and computer-integrated manufacturing, second edition, PHI.

Gupta, D., (1993). On measurement and valuation of manufacturing flexibility. International Journal of Production Research, 31(12), 2947-2958.

Hayes R. H., Wheelwright S. C., and Clark K. B., (1988). Dynamic Manufacturing, Free Press, New York.

Hayes, R. H. and Wheelwright, S. C., (1984). Restoring Our Competitive Edge. John Wiley, New York.

Hutchinson, J., (1991). Current and future issues concerning FMS scheduling. Omega, 19(6), 529-719.

Hyun, J. and Ahn, B. H., (1992). A unifying framework for manufacturing flexibility. Manufacturing Review, 5(4), 251-260.

Jayaram, J., Droge, C., and Vickery, S. K., (1999). The impact of human resource management practices on manufacturing performance. Journal of Operations Management, 18(1), 1-20.

Joshi, D., Nepal, B., Rathore, A. P. S., and Sharma, D., (2013). On supply chain competitiveness of Indian automotive component manufacturing industry. Int. J. Production Economics, 143, 151-161.

Kapoor, A., (2011).When states Race. Opening essay, Business world, May 2011.

Karima, M. A., Smith, A. J. R., Halgamuge, S. K., and Islam, M. M., (2008). A comparative study of manufacturing practices and performance variables. Int. J. Production Economics, 112, 841-859.

Karuppan, K. C. and Ganster, C. D., (2004). The Labourmachine dyad and its influence on mix flexibility. Journal of Operations Management, 22, 533-556.

Koste, L. L. and Malhotra, K. M., (1999). A theoretical framework for analyzing the dimensions of manufacturing flexibility. Journal of Operations Management, 18, 75-93.

Kumar, R., Jain, P. K., and Uma, M. K, (2008). Various Manufacturing System Paradigms: A Bird's Eye View. Proceedings of National Conference on Recent
Developments in Mechanical Engineering (MANTHAN 2008), GRKIST, Jabalpur, India.

Kwasi, A. G. and Moses, A., (2008). Manufacturing strategy, competitive strategy and firm performance: An empirical study in a developing economy environment. Int. J. Production Economics, 111, 575592.

Leong, G. K., Snyder, D., and Ward, P. T., (1990). Research in the process and content of manufacturing strategy. Omega, 18, 109-122.

Li, H., Li, V., Skitmore, M., Wong J., and Cheng. E., (2009). Competitiveness Factors: A Study of the Real Estate Market in China. Construction Management and Economics, 27(1), 567-569.

Malhotra, M. K. and Ritzman, L. P., (1990). Resource flexibility issues in multistage manufacturing. Decision Sciences, 21, 673-690.

Malhotra, N. K. and Dash, S., (2011). Marketing Research: An Applied Orientation. Sixth edition Pearson Publication, 279-280 \& 695-696.

Mehmet, D., Seckin, N. S., and Mehmat, C., (2013). Micro-economic competitiveness: a research on manufacturing firms operating in TRB1region. 2nd International Conference on Leadership, Technology and Innovation Management, Procedia-Social and Behavioral Sciences, 75, 465-472.

Polakoff, J. C., (1991). Reducing manufacturing costs by reducing cycle time. Corporate Controller, 4(2), 6264.

Porter, M. E., (1990). The Competitive Advantage of Nations, New York: Free Press.

Porter, M. E., (1996). What is strategy? Harvard Business Review, 74, 61-78.

Prahalad, C. K. and Hamel, G., (1990). The Core Competence of The Corporation. Harvard Business Review, 68(3), 79-91.

Ramasesh, R. V. and Jayakumar, M. D., (1991). Measurement of manufacturing flexibility: a value based approach. Journal of Operations Management, 10(4), 446-468.

Rojoka, J., (2009). Baltic States Competitiveness: Before and After the Global Crisis. Applied Economics: Systamatic Research, 3(1), 27-46.

Salloum, M. (2013). Explaining the Evolution of Performance Measures - A Dual Case-Study Approach. Journal of Engineering, Project, and Production Management, 3(2), 99-106.

Schuller, B. and Lidbom, M., (2009). Competitiveness of Nations in the Global Economy. Is Europe Internationally Competitive? Economics and Management, 14(1), 934-941.

Sethi, A. K. and Sethi, P. S., (1990). Flexibility in manufacturing: A survey. International Journal of Flexible Manufacturing Systems, 2, 289-328.

Slack, N., (1988). Manufacturing systems flexibility an assessment procedure. Computer-integrated manufacturing systems, 1(1).

St. Paul, M. N. and Cronbach, L. J., (1951). Coefficient alpha and the internal structure of tests. Psychometrika, 16, 297-334.

Swamidass, P. M. and Newell, W. T., (1987) Manufacturing strategy, environmental uncertainty and performance: A path analytic model. Mgmt Sci., 33, 509-524.

Tomas, V., (2011). National Competitiveness and Expenditure on Education, Research and 
Development. Journal of Competitiveness Issue 2, 2011.

Tracey, M., Vonderembse, A. M., and Lim, J., (1999). Manufacturing technology and strategy formulation: keys to enhancing competitiveness and improving performance. Journal of Operations Management, 17, 411-428.

Upton, D., (1994). The management of manufacturing flexibility. California Management Review, Winter, 72-89.

Wernerfelt, B., (1984). Resource-Based View of the Firm. Strategic Management Journal, 5(2), 171-180.

Zhang, Q., Vonderembse, A. M., and Lim, J., (2003). Manufacturing flexibility: defining and analyzing relationships among competence, capability, and customer satisfaction. Journal of Operations Management, 21, 173-191.

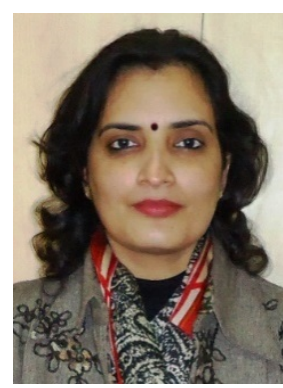

Ms. Shakun Preet Kaur is working as Assistant Professor in Department of Civil and Mechanical Engineering, School of Engineering at GD Goenka University, Gurgaon, India. She is pursuing her $\mathrm{PhD}$ from NIT Kurukshetra, India. She is M. Tech (Distinction) in Machine Design and B. Tech in Mechanical Engineering from PTU Jalandhar, India. She has a total experience of 11 years in teaching. She is a qualified internal ISO auditor and also a lifetime member of the ISTE. Her interests are research in the areas of Metallurgy, Total Quality Management, Design of Manufacturing Systems and Industrial Engineering. She has contributed in more than 10 research papers in National and international conference proceedings and Journals.

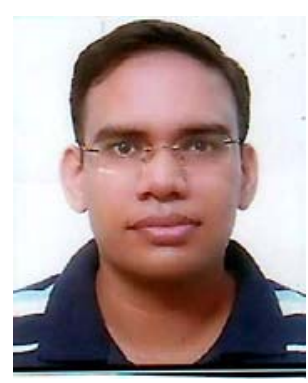

Dr. Jatinder Kumar is Assistant Professor in the Department of Mechanical Engineering, NIT Kurukshetra. He obtained his $\mathrm{PhD}$ in the field of unconventional machining from Department of Mechanical Engineering, Thapar University, Patiala (Punjab), India. He is a life member of ISTE. He has published more than thirty papers in international journals, national journals and conference proceedings. He has also reviewed many papers for refereed international journals of reputed publishers such as Taylor \& Francis, Springer and NISCAIR, India. He has supervised eight M.E. theses. He is supervising six $\mathrm{PhD}$ theses currently. His areas of interest are advanced manufacturing techniques, CNC Wire EDM, Ultrasonic machining, lean manufacturing.

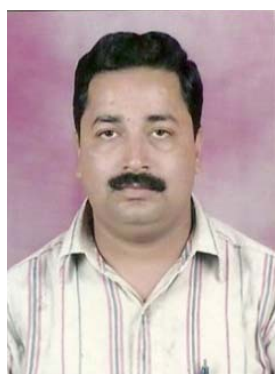

Dr. Rakesh Kumar is Associate Professor in the Department of Mechanical Engineering, SBS State Technology Campus (A Punjab Govt. Establishment), India. He obtained his $\mathrm{PhD}$ in the field of Reconfigurable Manufacturing Systems (CIMS-CAM) from Manufacturing Systems Lab., Department of Mechanical \& Industrial Engineering Indian Institute of Technology (IIT), Roorkee, India. He is a life member of ISTE and Member, Society of Operations Management. He has published more than forty papers in International journals, National journals and conference proceedings. His areas of interest are Relational studies of social and cultural evolution and emergence of contemporary paradigms of Manufacturing Systems, Simulation Modeling of Manufacturing Systems, Manufacturing Systems (RMS, CMS)/ G.T., Cleaner Production Systems/ C. P. A. 


\section{Appendix}

Following are certain statements regarding components of manufacturing system in your plant. Rate these as per following scale:

\begin{tabular}{|l|c|c|c|c|}
\hline 1: Strongly Disagree & 2: Disagree & $\begin{array}{c}\text { 3: Neither Agree nor } \\
\text { Disagree }\end{array}$ & 4: Agree & 5: Strongly Agree. \\
\hline
\end{tabular}

\begin{tabular}{|c|c|c|c|c|c|c|}
\hline MAC 1 & $\begin{array}{l}\text { The time required for a machine to start producing a new product } \\
\text { is short. }\end{array}$ & 1 & 2 & 3 & 4 & 5 \\
\hline MAC 2 & Total number of operations that a machine can perform is high. & 1 & 2 & 3 & 4 & 5 \\
\hline MAC 3 & Computer operated automatic machinery is used. & 1 & 2 & 3 & 4 & 5 \\
\hline MAC 4 & High machine availability, when change in product mix. & 1 & 2 & 3 & 4 & 5 \\
\hline MAC 5 & Machinery is designed to accommodate quick changeovers. & 1 & 2 & 3 & 4 & 5 \\
\hline MAC 6 & Machinery is designed to accommodate new fixtures. & 1 & 2 & 3 & 4 & 5 \\
\hline MAC 7 & $\begin{array}{l}\text { Tool change between operations in plant are (manual (1) to } \\
\text { automatic (5)). }\end{array}$ & 1 & 2 & 3 & 4 & 5 \\
\hline MAC 8 & $\begin{array}{l}\text { The percentage of total number of operations used in a plant that a } \\
\text { single machine can perform is high. }\end{array}$ & 1 & 2 & 3 & 4 & 5 \\
\hline MH 1 & $\begin{array}{c}\text { Material handling systems used is designed to support quick } \\
\text { changeovers. }\end{array}$ & 1 & 2 & 3 & 4 & 5 \\
\hline MH 2 & $\begin{array}{l}\text { Extent to which the material handling system can depart from its } \\
\text { normal flow and move materials in alternative paths is high. }\end{array}$ & 1 & 2 & 3 & 4 & 5 \\
\hline MH 3 & $\begin{array}{l}\text { Extent to which the material handling system can handle different } \\
\text { sizes and shapes of work is large. }\end{array}$ & 1 & 2 & 3 & 4 & 5 \\
\hline MH 4 & $\begin{array}{l}\text { Handling of work is automatic (fully manual (1) to fully automatic } \\
\qquad \text { (5)). }\end{array}$ & 1 & 2 & 3 & 4 & 5 \\
\hline W 1 & $\begin{array}{l}\text { The workers are capable to work on more than one machine at a } \\
\text { time. }\end{array}$ & 1 & 2 & 3 & 4 & 5 \\
\hline W 2 & $\begin{array}{l}\text { The workers are comfortable to work on machine with multiple } \\
\text { operations. }\end{array}$ & 1 & 2 & 3 & 4 & 5 \\
\hline W 3 & The ability of workers to operate various machines is high. & 1 & 2 & 3 & 4 & 5 \\
\hline W 4 & $\begin{array}{c}\text { The ability of the worker to handle altering of working methods is } \\
\text { high. }\end{array}$ & 1 & 2 & 3 & 4 & 5 \\
\hline W 5 & When change in demand skilled workers availability is no issue. & 1 & 2 & 3 & 4 & 5 \\
\hline W 6 & $\begin{array}{l}\text { The workers can be easily transferred between organizational } \\
\text { units/different departments. }\end{array}$ & 1 & 2 & 3 & 4 & 5 \\
\hline W 7 & $\begin{array}{c}\text { When change in product design skilled workers availability is no } \\
\text { issue. }\end{array}$ & 1 & 2 & 3 & 4 & 5 \\
\hline
\end{tabular}


76 Kaur, S. P., Kumar, J., and Kumar, R.

Following are certain statements related to the activities/strategies in your plant. Rate these as per following scale:

\begin{tabular}{|l|c|c|c|c|}
\hline 1: Strongly Disagree & 2: Disagree & $\begin{array}{c}\text { 3: Neither Agree nor } \\
\text { Disagree }\end{array}$ & 4: Agree & 5: Strongly Agree. \\
\hline
\end{tabular}

Plb $1 \quad$ We are able to provide a large range of products.

$1 \quad 2 \quad 3 \quad 4 \quad 5$

Plb 2 We are able to change the design of the existing product at low cost.

Plb 3 We are able to launch new products at low cost.

$\begin{array}{lllll}1 & 2 & 3 & 4 & 5\end{array}$

Plb 4 We are able to launch products with latest technology and design

Plb $4 \quad$ in comparison to our competitors.

PRICE $1 \quad$ We offer competitive prices.

$\begin{array}{lllll}1 & 2 & 3 & 4 & 5\end{array}$

PRICE $2 \quad$ We are able to compete based on our prices.

PRICE $3 \quad$ We are able to profitably offer as low as our competitor.

DEL 1 We provide on time delivery of orders.

DEL 2 We accommodate variation in order sizes without affecting our

$$
\text { delivery performance. }
$$

DEL 3 We can alter our delivery schedule as per each customers requirement.

DEL $4 \quad$ Our frequency of customer back orders is low.

QLTY 1 We produce products that conform to specifications of our customers.

QLTY 2 The percentage of warranty or guarantee claimed on products to total manufactured products is decreasing.

QLTY 3

We are able to compete based on quality.

QLTY 4

We offer reliable and durable products.

$\begin{array}{lllll}1 & 2 & 3 & 4 & 5 \\ 1 & 2 & 3 & 4 & 5\end{array}$

$\begin{array}{lllll}1 & 2 & 3 & 4 & 5\end{array}$

$\begin{array}{lllll}1 & 2 & 3 & 4 & 5\end{array}$

$\begin{array}{lllll}1 & 2 & 3 & 4 & 5\end{array}$

$1 \quad 2 \quad 3 \quad 4 \quad 5$

$\begin{array}{lllll}1 & 2 & 3 & 4 & 5\end{array}$

$\begin{array}{lllll}1 & 2 & 3 & 4 & 5\end{array}$

$\begin{array}{lllll}1 & 2 & 3 & 4 & 5\end{array}$

$\begin{array}{lllll}1 & 2 & 3 & 4 & 5\end{array}$

\section{QLTY 4}

We offer reliable and durable products. 